\title{
Quantifying Market and Non-Market Benefits and Costs of Hydraulic Fracturing in the United States: A Summary of the Literature
}

\author{
ABSTRACT \\ We quantify the monetary market and non-market environmental benefits and costs of hydraulic \\ fracturing in the 14 U.S. states whose oil and gas production is dominated by hydraulic \\ fracturing. By far the largest market benefit is $\$ 75$ billion ( $\$ 46-\$ 95$ billion) in consumer surplus \\ from lower natural gas prices to residential, commercial, and industrial consumers. There are \\ also environmental benefits resulting from the switch by some electric utilities from coal to \\ natural gas ( $\$ 13.25$ billion, range $\$ 3.9$ - $\$ 21.9$ billion). However, there are also substantial \\ environmental costs associated with hydraulic fracturing. These are dominated by $\$ 27.2$ billion \\ ( $\$ 12.5$ - $\$ 41.95$ billion) health damages from air pollution. Costs also include $\$ 3.8$ billion ( $\$ 1.15$ \\ - $\$ 5.89$ billion) in greenhouse gas emissions, $\$ 4$ billion ( $\$ 3.5$ - $\$ 4.45$ billion) in wildlife habitat \\ fragmentation, and $\$ 1$ billion ( $\$ .5$ - $\$ 1.6$ billion) in pollution of private drinking water wells. \\ Opportunity costs of water usage and property value losses are less than one-quarter of a billion \\ dollars. The market and non-market benefits of hydraulic fracking are widespread geographically \\ but many of the non-market costs are concentrated in the areas of drilling, creating a \\ distributional disconnect that we believe drives much of the controversy over hydraulic \\ fracturing. \\ Keywords: \\ Benefit-cost analysis \\ Hydraulic fracturing \\ Environmental costs \\ Market benefits
}




\section{Introduction}

Hydraulic fracturing combined with horizontal drilling has made the extraction of oil and gas from certain types of geologic formations economically feasible, increasing the available energy resources in the U.S. and inducing an oil and gas "boom" in certain parts of the country. The percentage of natural gas extracted using hydraulic fracturing has increased dramatically from 23\% in 2011 (API, 2013) to at least 50\% in 2015 (Prince and Tovar, 2015) and as much as two-thirds according to the very latest U.S. Energy Information Administration (USEIA, 2016a). These estimates are consistent with earlier estimates by the U.S. Energy Information Administration (USEIA 2015a,b) and Jackson, et al. (2013) who report that well over half of the 2014 natural gas production in the U.S. was from tight gas and shale formations, produced using hydraulic fracturing.

Some states such as North Dakota, citing economic benefits, have openly embraced hydraulic fracturing, while other states such as New York have banned the procedure because of environmental concerns. As illustrated by this contrast, the public debate has been framed as a choice between economic benefits and environmental quality. This misperception is easy since most of the benefits are reflected in markets and most of the costs are non-market environmental costs. As our analysis will show this is a false dichotomy: environmental quality produces economic benefit, and can be compared to the economic benefits flowing to society from hydraulic fracturing.

Sovacool (2014) catalogs the categories of benefits and costs of hydraulic fracturing, and provides some quantification of the employment and environmental impacts. However, the author does not provide a monetization of most of the market and non-market effects. Similarly, Mehany and Guggemos (2015) provide a brief review of six categories of environmental impacts from hydraulic fracturing and three economic effects. However, no comparative monetization of environmental costs and economic effects is made. Hausman and Kellogg (2015) and Mason, et al. (2015) both stress that while the market benefits of hydraulic fracturing are substantial that further research is needed to quantify the environmental costs. Our paper uses the existing gray and published literature to calculate the monetary values of most environmental impacts. We also provide some refinement of estimates of the market benefits.

The results of our analysis on the market and non-market environmental effects of hydraulic fracturing also allow us to shed some light on the issue of the distribution of these 
benefits and costs. We believe it is the disconnect between those who benefit from hydraulic fracturing (natural gas consumers and industries throughout the country; oil and gas workers, mineral owners) and those who bear the costs (those living around hydraulically fractured wells) that is at the root of the contentious debate. Our findings on the magnitude of benefits relative to costs suggest an opportunity for better mitigation of the costs of environmental impacts.

\section{Theory and Methods}

The overall conceptual framework of our assessment is benefit-cost or economic efficiency analysis. Economic benefits are defined as the consumer surplus and producer surplus (Just, et al. (2004)). Benefits and costs include both market and non-market values, including opportunity costs. We should note that commonly cited economic benefits of hydraulic fracturing such as jobs, higher wages, taxes paid by industry and royalties are a cost to the firm, and hence reduce producer surplus. Put another way, while all of these items are benefits to the recipients they are costs to the firm, and therefore they net out from the stand point of an economic efficiency analysis. Further, in most cases jobs gained in one geographic region or industry reflect a transfer of workers from other geographic regions or industries (Sassone and Schaffer, 1978: 71; Loomis, 2002).

We have focused our analysis on the following effects arising from hydraulic fracturing: consumer surplus from lower natural gas prices, net changes in emissions of greenhouse gas and air pollutants, water issues (quantity and quality), residential property values and wildlife habitat fragmentation. For each of these effects we have found data sources in the literature. We focus on quantifying these effects for 14 states where either nearly all oil and gas production depends on hydraulic fracturing or a substantial portion of all new production has come from hydraulic fracturing (Arkansas, California-on shore, Colorado, Louisiana-on shore, Montana, New Mexico, North Dakota, Ohio, Pennsylvania, Texas, Utah, West Virginia, and Wyoming). Further, much of our analysis is driven specifically by the number of hydraulically fractured wells (e.g., emissions, water used) which allowed us to calculate monetary valuation associated with hydraulic fracturing. We used the most up-to-date information on the number of hydraulically fractured wells from www.fractracker.org and other sites such as U.S. Energy Information Administration (USEIA). However, there is a time lag in all literature and even web based sources so our base year for the number of drill rigs and production is 2014 (using data through the end of the year). Therefore our analysis, like most analyses dependent on data reported with a 
time lag, misses any impacts since then. Although with the large drop in oil and gas prices in 2016, new drilling activity appears to have fallen dramatically in the U.S. It is also important to acknowledge an implicit assumption underlying our analysis: that hydraulic fracturing represents new net impacts in the United States. That is, in the absence of hydraulic fracturing the U.S. would continue to do what it did prior to hydraulic fracturing, which was a combination of domestic conventional wells and importing a substantial fraction of its fossil fuels. Of course importing fossil fuels to the U.S. is not without global environmental impacts, but these are beyond the scope of our analysis, and hence a limitation of our analysis. If U.S. hydraulic fracturing did displace some conventional domestic oil and gas production then our estimates of the impacts attributable to hydraulic fracturing would be overstated. However, data from the U.S. Energy Information Agency (2016c) documents the increase in total oil and gas production over the last twenty years, and suggests hydraulic fracturing may have displaced a portion of domestic conventional gas wells, but not oil wells. The reader should keep these qualifications to our analysis in mind.

Other effects discussed but not quantified include the potential consumer surplus from the reduced price of oil, and environmental effects such as aesthetic losses to non-property owners and induced seismic activity. We acknowledge that our list is not a complete accounting of all the costs and benefits but to our knowledge the most comprehensive to date.

\section{Results}

\subsection{Impacts of Lower Natural Gas Prices}

Wholesale natural gas prices in the U.S. have dropped to less than half the level before widespread adoption and implementation of hydraulic fracturing (Hausman and Kellog 2015, Holladay and LaRiviere 2014). Lower natural gas prices attributed to hydraulic fracturing, have generated a significant increase in consumer surplus for natural gas customers, whether they be households (for home heating), the electric power sector, industrial users or commercial users (Hausman and Kellogg 2015). In addition, the lower natural gas prices have led to fuel switching from coal to natural gas for electricity production (Holladay and LaRiviere 2013, Center for Climate and Energy Solutions 2013) which has environmental benefits.

Hausman and Kellogg (2015) perform a monthly time series analysis to estimate demand functions for residential, commercial, industrial and electric power users of natural gas. They 
then calculate an increase in consumer surplus of $\$ 75$ billion per year due to lower natural gas prices resulting from the increased supply enabled by hydraulic fracturing. The authors' sensitivity analysis with respect to natural gas demand and supply elasticities results in a range from a minimum benefit of $\$ 46$ billion to a maximum of $\$ 95$ billion. These gains from lower natural gas prices are shared across users with $23 \%$ accruing to residential customers, $15 \%$ to commercial users, $30 \%$ to industrial users and $33 \%$ to the electric power sector (Hausman and Kellogg, 2015: 17). The benefits are also very broadly distributed throughout the country (Hausman and Kellogg, 2015: 18).

However, the lower natural gas prices also affect the producer surplus for natural gas firms. Calculation of producer surplus is done by subtracting the price from firm's variable costs (Just, et al., 2004: 55). Data on the price of natural gas were obtained from Hausman and Kellog (2015: 16). Variable production costs per thousand cubic feet (Mcf) of gas were obtained from a report prepared for the U.S. Energy Information Administration (EIA, 2016c) for the two major shale gas plays (accounting for approximately half the shale gas production in the U.S.). The producer surplus associated with shale gas production amounts to $\$ 7.24$ billion annually. However, the lower natural gas prices discussed above (Hausman and Kellogg, 2015; Holladay and LaRiviere 2013) also suggests that companies with previously completed conventional gas wells have experienced a reduction in producer surplus on these wells (Hausman and Kellogg, 2015). Thus our estimate of the gain in producer surplus from shale gas wells is partially offset by the reduction in producer surplus to conventional gas wells.

These calculations focus only on the reduction in natural gas prices, and do not consider the impact of lower oil prices. Analyzing the effect that hydraulic fracturing has had on oil prices is complicated by the fact that the price of crude oil is more influenced by world production and because oil more easily transported than natural gas. Therefore we have left this effect unquantified.

\subsection{Property Value Effects}

As hydraulic fracturing has moved into suburban and urban areas particularly in Pennsylvania, Ohio, Texas, and Colorado, citizens have mobilized into active opposition based, in part, on the potential negative impact on property values. However, housing the workforce necessary for hydraulic fracturing results in increased demand for housing which may drive 
housing values up, as has been the case in parts of North Dakota (Platt, 2013) and Texas (Lopez, 2012).

These effects are examined using the hedonic property method (HPM) which presumes that in order for households to accept living near a less desirable environment, they must be compensated by lower house prices. To isolate the effect of hydraulic fracturing on house prices as distinct from other structural and neighborhood features of a house, the HPM uses multivariable regression. Table 1 summarizes the key HPM studies that we relied upon to estimate the effect of hydraulic fracturing on property values in the 14 states studied.

Table 1. Summary of effects of oil \& gas drilling and production on home prices estimated using the hedonic property method unless otherwise noted.

\begin{tabular}{llcl}
\hline \multirow{2}{*}{ Location } & Type of Property & $\begin{array}{c}\text { \% Change in } \\
\text { Property Value }\end{array}$ & Author(s) \\
\hline \multirow{2}{*}{ Weld County, CO } & Drilling within 1/2 mile of property & $-1 \%$ & Bennett \& Loomis \\
\cline { 2 - 4 } & Oil \& Gas employment & $+0.2 \%$ & \\
\hline \multirow{2}{*}{$\begin{array}{l}\text { Western Colorado } \\
\text { counties }\end{array}$} & Within 1 mile, no mineral rights, well water & $-33 \%$ & \multirow{2}{*}{ Boslett et al. 2015 } \\
\cline { 2 - 4 } Pennsylvania & Within 2 miles, no mineral rights, well water & $-20 \%$ & \\
\cline { 2 - 5 } Texas & Drilling within 1 mile, house not on well water & $-3 \%$ to 6\% & Muehlenbachs, et \\
\hline $\begin{array}{l}\text { Texas, Flower } \\
\text { Mound near Denton }\end{array}$ & Willingness to Pay of homeowners in Texas* & $-6 \%$ to $-14 \%$ & Throupe, et al. \\
\hline
\end{tabular}

*Performed using a contingent valuation method survey of homeowners.

As can be seen in Table 1, most of the HPM analyses of the influence of hydraulic fracturing have been on homes within 1 mile of hydraulically fractured wells. The effects are fairly small (-1 to $-3 \%)$ except for houses on well water that face the potential for contamination of their drinking water. Hydraulic fracturing can also expose nearby households to air pollution (McKenzie, et al. 2016), noise from drilling activity, and truck traffic back and forth to the well site. These effects will be capitalized into house prices. However, as noted below in the section on air quality, there are emissions of volatile organic compounds (VOC's) and NOx from hydraulic fracturing operations that result in ground level ozone that can affect the health of people living more than 1 mile away from hydraulic fracturing well pads. So while there may be 
some potential for double counting of air pollution damages calculated in the air quality section we believe that effect is minimal.

Ideally a full 14 state GIS analysis of each and every well and its distance to each and every house would be undertaken. However, such a task for 14 states would be a major study itself. Thus, a more pragmatic approach is adopted here. First, we evaluate property value losses from hydraulic fracturing in states with their own original property value study. Then we apply the percentage reduction in property values from the states with original studies to neighboring states or states within the same geographic region. This percentage reduction is combined with those states own data on the number and locations of oil and natural gas wells, the number of houses, and median house price from each of these neighboring states or states within the same region. The total estimated residential property value loss across the 14 states is $\$ 258$ million, ranging from a low of $\$ 148$ million to a high of $\$ 325$ million, with the majority of the losses in high population states where a substantial portion of oil and production uses hydraulic fracturing.

\subsection{Water Quantity Issues}

Hydraulic fracturing requires the injection of water mixed with sand and chemicals into wells. Nationally, all water withdrawals for hydraulic fracturing represents less than $1 \%$ of total use and consumption (U.S. EPA, 2015:ES-7). For three of our study states we have state-specific studies that estimate water withdrawals for hydraulic fracturing. For Texas (with $60 \%$ of the national water withdrawals) we use Nicot and Scanlon (2012); for California we use Long, et al. (2015); and for Colorado we use Waskom, et al. (2015). For the rest of the states we use estimates from EPA (2015: Appendix B) to calculate the quantity of water used.

The value of water is most often determined by its value marginal product (VMP) which reflects the value of output produced and the marginal productivity of water. Other sectors are able to purchase or lease water from agriculture because the VMP of water for the vast majority of irrigated agriculture is, on average, quite low. Therefore, the amount of compensation required by farmers to willingly sell or lease a portion of their irrigation water (i.e., their producer surplus foregone) for use in hydraulic fracturing is also relatively low. So it is not surprising that water is available for hydraulic fracturing at minimal cost to the economy. We use several estimates (adjusted for inflation to 2014) to derive the opportunity cost of water for hydraulic fracturing in our 14-state study area. 
For New Mexico, we use estimates from Ward and Michelsen (2002: 431, 443) for the value of agricultural water in New Mexico's Rio Grande Basin. Michelsen and Lacewell (2013) estimate the opportunity cost of the various sources of water used in hydraulic fracturing for Texas, and we use these values for both Texas and Oklahoma. For Colorado we relied upon a recent study by Swanepoel, et al. (2015) of the eastern plains region, where a substantial amount of hydraulic fracturing is taking place. For Utah and Wyoming we relied upon estimates from Colby (1989: 522). For the remainder of the 14 study states we used USDA's estimated average values for surface water costs for various regions of the U.S. (Gollehon and Quinby, 2006; Gollehon, et al. 2003). Across all our 14 states the total value of water used in hydraulic fracturing is roughly $\$ 21.85$ million.

\subsection{Non-Market Environmental Effects}

\subsubsection{Air Quality Effects}

As noted by Mason, et al. 2015, oil and gas production in general, and production using hydraulic fracturing in particular, has both positive and negative effects on air quality. A positive effect is the reduction of $\mathrm{CO}_{2}$ emissions from the substitution of cheaper natural gas for coal in electricity production. This fuel substitution also reduces air pollution in the geographic regions around and downwind from power plants. However, negative effects of hydraulic fracturing on air quality include increases in local emissions of air pollutants, especially affecting residents who live near wells.

In order to determine how much of the emissions generated from oil and gas production are from operations relying on hydraulic fracturing, we compare emissions from oil and gas production before hydraulic fracturing became common place with emissions generated by the industry after the technique was widely adopted. Taking into consideration the availability of detailed data on emissions, we will use 2005 as our dividing line between pre- and post-hydraulic fracturing. This starting point is consistent with Holladay and LaRiviere's (2014) analysis and is similar to the 2007 date used by Mason et al. (2015). The 2005 date is also consistent with U.S. EIA (2015a,b) statistics which show about $10 \%$ of oil production and $15 \%$ of gas production was attributable to hydraulic fracturing in 2005. Using the difference in production between 2005 and 2015 somewhat understates the contribution of hydraulic fracturing to estimates of air pollution and greenhouse gas emissions. 
According to EPA, the National Academy of Sciences report (Institute of Medicine, 2013), Adgate, et al. (2014), and Thompson, et al. (forthcoming) the types of air pollutants generated by oil and gas development include: (1) Volatile Organic Compounds (VOC's) that form ground level ozone; (2) Nitrogen Oxides (NOx); and (3) Particulate Matter of 2.5 microns (PM2.5). There are also emissions of greenhouse gases, particularly methane (Howarth, et al. (2011; IPCC, 2007; USEPA, n.d.) which is a very potent greenhouse gas with a global warming potential about 21-25 times that of $\mathrm{CO}_{2}$.

The health effects of ground level ozone include asthma with severity ranging from minor effects related to restricted activity days (where one is unable to perform normal activities) to severe effects requiring emergency room visits (EPA n.d.) and even premature death. The health effects of PM2.5 include bronchitis, non-fatal acute myocardial infarction (heart attack) and hospitalization for respiratory symptoms (Fann, et al. 2009).

The remainder of Section 3.2.2 on effects of hydraulic fracturing on air quality is organized as follows. First we quantify the amount of air pollution and greenhouse gas emissions from natural gas wells. Second we use the literature to calculate the damages in dollars per ton from each pollutant. Next we estimate the benefits of reduced greenhouse gas emissions from switching from coal to natural gas. Then in the last part of this section we combine the damages and benefits to arrive at aggregate monetary effects of hydraulic fracturing on air quality and greenhouse gases.

\subsubsection{Quantifying Air Pollution Emissions from Natural Gas Wells}

Air pollution from natural gas wells that are hydraulically fractured, arises from numerous sources including diesel engines on drilling rigs themselves, support truck traffic, methane leakage and venting, flow-back, and long term production facilities. We have relied upon estimates from Litovitz, et al. (2013) for data on emissions of VOC, NOX, SOX and PM2.5 per well at the three typical stages of production: (a) well site development; (b) well site production; (c) compressor station emissions. We obtained total number of active gas wells by state for our 14 states from the U.S. Energy Information Agency. ${ }^{1}$ While Litovitz et al.'s data are for Pennsylvania, the same Marcellus Shale Play that underlies Pennsylvania also underlies the producing areas in West Virginia and eastern Ohio. Collectively these three areas represent one-

\footnotetext{
${ }^{1}$ https://www.eia.gov/dnav/ng/ng_prod_wells_s1_a.htm
} 
third of the total number of hydraulically fractured wells according to USGS. No doubt there is some variability in emissions from (a) and (b) among the shale plays in the other 11 states that make up the remaining two-thirds of production. Thus this is an important avenue for future refinement of our estimates when such data become available.

\subsubsection{2 .Greenhouse Gas Emissions Associated with Hydraulic Fracturing of Gas Wells}

A complete accounting of greenhouse gas emissions related to hydraulic fracturing would need to factor in: (a) releases of methane and $\mathrm{CO}_{2}$ at the drill sites, processing, transmission, storage and distribution; (b) combustion of the fuel. Lower natural gas prices would certainly result in an increase in its use, which could potentially increase greenhouse gas emissions. However, the lower natural gas prices have primarily led to fuel switching from coal to natural gas for electricity production (Holladay and LaRiviere 2013, Center for Climate and Energy Solutions 2013; Newell and Raimi 2014) which, as discussed in the next section, results in a reduction in overall greenhouse gas emissions in our analysis. However, Hausman and Kellogg's (2015) scenario analysis suggests that with the highest methane leak rates reported in the literature, combined with the increase end use of natural gas can result in net increases in greenhouse gas emissions with hydraulic fracturing. This highlights the importance of methane leak detection and rapid response.

To estimate the rate of greenhouse gas emissions per Mcf of natural gas, we started with EPA's (2010a) estimate of the $\mathrm{CO}_{2}$ equivalents from methane emissions plus direct $\mathrm{CO}_{2}$ emissions in 2008 (the latest year available in their report). For methane emissions related to natural gas production we included all phases from field production, processing, transmission, storage and distribution. We divided those $\mathrm{CO}_{2}$ equivalent emission estimates by natural gas production (in billion Mcf) in 2008. This yielded $\mathrm{CO}_{2}$ or equivalent emissions per Mcf. Using the per Mcf emissions and Prince and Tovar's (2015) estimate of natural gas production using hydraulic fracturing at the end of 2014, we estimate 91.78 million tons of $\mathrm{CO}_{2}$ and equivalents were emitted in 2014 from hydraulic fracturing operations.

\subsubsection{Air pollution reductions from substitution of natural gas for coal in electricity production}

As noted previously, the substitution of natural gas for coal in electricity production has resulted in reductions in air pollutants from power plants that have switched to natural gas. To calculate this reduction, we used emissions (pounds of $\mathrm{CO}_{2}, \mathrm{SOX}$ and $\mathrm{NOX}$ ) per megawatt hour 
of electricity from the Center for Climate and Energy Solutions (2013). We then used Electricity Net Generation for the Electric Power Sector from the U.S. Energy Information Administration's (2015c) Monthly Energy Review. Following Holladay and LaRiviere (2013) we used an earlier year (2005) as our baseline because output of natural gas and oil from hydraulic fracturing was minimal at that point (Prince and Tovar, 2015). In 2005 electricity production was dominated by coal at nearly 1,999 million megawatt hours, compared to natural gas at 684 million megawatt hours. By 2012, natural gas generated 1,133 million megawatt hours of electricity and coal had fallen to 1,500 million megawatts. Since electricity generated using natural gas produces about half the $\mathrm{CO}_{2}$ emissions per megawatt hour compared to coal, less than one-tenth the SOX, and about one-third the NOX, air pollution emissions dropped with this fuel shift, and dropped dramatically for SOX.

\subsubsection{Economic Valuation of Air Quality Effects on Human Health}

As described in Freeman (2003), economists have several techniques they use to estimate the economic damages from health effects from air pollution. Combining valuations with atmospheric modeling, air pollution concentration-human health response functions, and regional populations allowed Muller and Mendelsohn (2007:4-5) to provide a comprehensive analysis of the economic damages (i.e., mortality and morbidity) from a ton of emissions of each major air pollutant in both urban and rural areas. As noted by a reviewer, a large majority of hydraulically fractured wells are located in rural areas (e.g., AR, MT, ND, NM, OH, PA, UT, WV, and WY) so we have chosen to rely on Muller and Mendelsohn's rural estimates (updated for inflation) as a lower bound estimation of air pollution damages across our 14 states (see the first row of Table 2).

However, even a few hydraulically fractured wells near suburban/metropolitan areas that have populations an order of magnitude larger than rural areas, would contribute a substantial amount of air pollution damages. Inspection of general locations of hydraulically fractured wells at www.fractracker.org indicates that some states - onshore California, Colorado, onshore Louisiana, Oklahoma, and Texas - have substantial populations in close proximity to a significant number of these wells. Fann, et al. $(2009,2012)$ provides estimates of the damages per ton of air pollutants in metropolitan areas, several of which have nearby hydraulic fracturing. 
Ideally, to calculate a precise estimate of the 14 state weighted average air pollution exposure to hydraulic fracturing wells, a detailed GIS data analysis would be needed for each state. This would be a project in and of itself. Instead, we rely on data from Colorado to provide the population weighted average exposure in states with hydraulic fracturing in both rural and metropolitan areas. In Colorado about one-third of the state population (35\%, see McKenzie, et al. 2016) live in one of the three major shale plays in Colorado with very active drilling. To apply this number to the other 13 states where we do not have this data, we classify the 13 other states as either (a) states where drilling occurs in a mix of metropolitan/rural areas such as in California, Louisiana, Oklahoma and Texas or (b) nine states where drilling occurs in predominately rural areas. In the five states with a mix of metropolitan/rural areas we apply Fann et al.'s metropolitan values to 35\% of the population and Muller and Mendelsohn's rural values to $65 \%$ of the population to arrive at a weighted average value in that state. In the nine other states where drilling occurs mainly in rural area we apply Muller and Mendelsohn's rural values to that state. Next, to calculate a single overall 14 state average damage per ton, we weight each state's average damage per ton by the number of wells in each state. The resulting well-weighted average provides our upper bound estimate of damages per ton. Finally, to calculate our "best estimate" of the damage per ton, we use the mid-point of the well-weighted average upper bound and the all rural lower bound estimate. Table 2 presents the lower, upper and best estimates of the air pollution damages per ton.

Table 2. Damages per Ton of each Hydraulic Fracturing Related Pollutant (\$2015)

\begin{tabular}{llccc}
\hline Alternative Estimates & VOC & SOX & PM2.5 & NOX \\
\hline Low estimate-all Rural & $\$ 353$ & $\$ 1,058$ & $\$ 1,293$ & $\$ 353$ \\
$\begin{array}{l}\text { High estimate: Weighted Rural } \\
\text { \& Metropolitan average }\end{array}$ & $\$ 509$ & $\$ 6,343$ & $\$ 19,825$ & $\$ 821$ \\
Best Estimate-Mid point & $\$ 431$ & $\$ 3,701$ & $\$ 10,559$ & $\$ 587$ \\
\hline
\end{tabular}

\subsubsection{Economic Effects of Greenhouse Gas Emissions}

The official U.S. government social cost of carbon and greenhouse gas equivalents estimates (USEPA, 2016) are based on the damage estimates in the literature. These damage estimates reflect damages of carbon emissions (or other greenhouse gases) to agricultural productivity, human health, property damages from increased flood frequencies, and the 
reduction in the quantity and value of ecosystem services. The U.S. government estimates a middle range average of $\$ 41(\$ 2015)$ per ton of carbon at a 3\% discount rate which we use as the central value in our analysis below. To estimate a range of values we use the USEPA (2016) average value of $\$ 12.57$ per ton (5\% discount rate) and the upper range is the average damage per ton of $\$ 64$ calculated at a $2.5 \%$ discount rate.

\subsubsection{Summary of Economic Effects of Air Pollution and Greenhouse Gas Emissions}

Table 3 presents a summary of the non-market air quality improvements and damages arising from hydraulic fracturing. The air quality health and greenhouse gas damages from hydraulic fracturing total $\$ 31$ billion, with nitrogen oxides (NOX) representing the about half of these damages in part because of the very high emissions of NOX estimated by Litovitz, et al. As shown in the lower half of Table 3, the substitution of natural gas for coal in electricity production results in a reduction in health damages of $\$ 5.87$ billion from reduced SOX, and $\$ 321$ million from reduced NOX and $\$ 947$ million from reductions in PM2.5. When the greenhouse gas emission reduction of $\$ 6.1$ billion is included, there is a total reduction of $\$ 13.25$ billion in damages from reduced air pollution related to the switch from coal to natural gas in electricity production. Nonetheless, overall, hydraulic fracturing results in a net damage cost (considering both costs and benefits) from air quality changes of $\$ 17.75$ billion, with a range from $\$ 9.76$ billion to $\$ 25.9$ billion. $^{2}$

\footnotetext{
${ }^{2}$ The assumption that hydraulic fracturing results in changes in SOX and NOX assumes that cap-and-trade programs are not binding for these pollutants. This is the same assumption made by Holland, et al. (2016: 3726) in the context of estimating the environmental benefits of electric vehicles. They argue that the permit prices were "...exceedingly low in many markets..." as evidence that these permit markets are non-binding. We appreciate an anonymous reviewer pointing out this assumption in our analysis regarding the permit markets, and the similar assumption in Holland, et al.
} 
Table 3. Summary of Air Emission Damages (\$2015)

\begin{tabular}{|c|c|c|c|c|c|c|}
\hline \multicolumn{7}{|c|}{ Emissions \& Damages from Hydraulic Fracturing } \\
\hline & CO2 Eq. & SOX & NOX & VOC & PM2.5 & Total \\
\hline Emissions (Million tons) & 91.782 & 0.45 & 25 & 5.84 & 0.7716 & \\
\hline Damages ( $\$$ millions) & $\$ 3,776$ & $\$ 1,669$ & $\$ 14,884$ & $\$ 2,518$ & $\$ 8,148$ & $\$ 30,995$ \\
\hline \multirow{2}{*}{ Range $\begin{array}{c}\text { High } \\
\text { Low }\end{array}$} & $\$ 1,153$ & $\$ 477$ & $\$ 8,952$ & $\$ 2,063$ & $\$ 998$ & $\$ 13,633$ \\
\hline & $\$ 5,874$ & $\$ 2,860$ & $\$ 20,816$ & $\$ 2,974$ & $\$ 15,297$ & $\$ 47,821$ \\
\hline \multicolumn{7}{|c|}{ Reduced Emissions \& Benefits from Substituting Gas for Coal in Electricity Production } \\
\hline & CO2 Eq. & SOX & NOX & $V O C$ & PM2.5 & Total \\
\hline Emissions $^{\text {a }}$ (Million tons) & -149 & -1.6 & -0.55 & No data & -0.0896 & \\
\hline Damages $^{\mathrm{a}}$ (\$ millions) & $-6,109.00$ & $-\$ 5,870$ & $-\$ 321$ & & $-\$ 947$ & $-\$ 13,247$ \\
\hline \multirow{2}{*}{ Range $\begin{array}{c}\text { High } \\
\text { Low }\end{array}$} & $-\$ 1,872$ & $-\$ 1,693$ & $-\$ 194$ & & $-\$ 116$ & $-\$ 3875$ \\
\hline & $-\$ 9,536$ & $-\$ 10,149$ & $-\$ 451$ & & $-\$ 1,776$ & $-\$ 21912$ \\
\hline Net Total Damages & $-\$ 2,333$ & $-\$ 4,201$ & $\$ 14,563$ & $\$ 2,518$ & $\$ 7,201$ & $\$ 17,748$ \\
\hline \multirow{2}{*}{ Range $\begin{array}{l}\text { High } \\
\text { Low }\end{array}$} & $-\$ 719$ & $-\$ 1,216$ & $\$ 8,758$ & $\$ 2,063$ & $\$ 882$ & $\$ 9,758$ \\
\hline & $-\$ 3,662$ & $-\$ 7,289$ & $\$ 20,365$ & $\$ 2,974$ & $\$ 13,521$ & $\$ 25,909$ \\
\hline
\end{tabular}

The estimates in this table reflect natural gas wells only.

${ }^{a}$ Negative emissions indicate emission reductions and negative damages indicate benefits.

\subsubsection{Water Quality Issues}

A great deal of the controversy associated with hydraulic fracturing and water resources focuses on water quality. The pathways by which hydraulic fracturing can contaminate surface water resources include leakage from pits where flowback and produced water is stored, overflow from these storage pits, spills during transport of hydraulic fracturing fluids, other chemicals and waste (Kahrilas et al. 2015). Several studies document cases of water contamination due to oil and gas production (for example see Bowen et al. 2015, Jackson et al. 2013, Olmstead et al. 2013, Osborne et al. 2011, Vengosh et al. 2014). Produced water is the largest single waste stream from oil and gas development and is one potential source of surface and groundwater contamination (Clark and Veil 2009). 


\subsubsection{Economic Effects of Surface Spills on Private Drinking Water Wells}

Chapter 10 of EPA (2015) provides spill frequency rates for two of the more researched states - Colorado and Pennsylvania. The Colorado data indicates one spill of hydraulic fracturing fluids, chemicals, and produced water for every 100 hydraulically fractured wells (approximately1\%). In Pennsylvania the rate is more variable ranging from 0.4 spills of these materials per 100 hydraulically fractured wells to 12.2 spills per 100 wells. We choose to focus on surface spills as neither Osborn, et al. (2011), Drollette, et al. (2015) nor Manning (2015) could find cases where any underground leakages had contaminated drinking water wells. As noted in EPA (2015) these contaminations do occasionally happen, but it is rare enough that it is difficult to find any rates of contamination.

According to Drollette, et al. (2015) it is these surface spills that often result in contamination of private drinking water wells in their study area in Pennsylvania. Their careful and exhaustive study matched reported hydraulic fracturing related environmental health violations to each of their study's private drinking water well sites, and using chemical signature analysis ruled out most other non-spill related sources. Diesel and gasoline related compounds were found in about one-third the private water wells sampled (Drollette, 2015:13185). One of those diesel related compounds was bis(2ethylehexyl) phthalate which the authors labeled as a "reasonably anticipated human carcinogen" (Drollete, et al., 2105: 13188).

Thus it is not surprising that Siikamaki and Krupnick (2014) find that respondents to their stated preference non-market valuation choice experiment survey would be willing to pay to reduce the risk of water contamination from hydraulic fracturing in Texas and Pennsylvania. To apply their dollar values we need two pieces of data: (a) spill or leakage rate per hydraulically fractured oil and gas well; and (b) the percentage of such spills that result in contamination of private drinking water wells. Together these form a compound probability.

For spill rate we rely upon EPA (Chapter 10, page 6) of 1 spill per 100 wells in Colorado as a proxy for the western U.S. and the mid-point of the reported spill rate in Pennsylvania (6\%) for the eastern U.S. For the sensitivity analysis, we use the lower and upper bounds of spill rates found in Pennsylvania (e.g., .4\% to 12.2\%). For contamination of drinking water wells conditional on spills we rely on Drollette, et al. (2015), who detected gasoline related or diesel related compounds (including a disclosed additive of hydraulic fracturing fluid) in $32 \%$ of drinking water well samples taken at hydraulic fracturing sites with reported spills. 
Combining the estimated number of contaminated private drinking water wells with Siikamaki and Krupnick's (2014) values per household to avoid contamination of private drinking water wells, and the number of households in each of the 14 states, yields estimated damages of about $\$ 1$ billion (with a range of $\$ 510$ million to $\$ 1.625$ billion).

\subsubsection{Surface water}

Many of the studies cited above note that produced water contains several detrimental constituents which are difficult to adequately remove in treatment. The same concern has been noted for hydraulic fracturing flowback water (Kappel et al. 2013, Rahm and Riha 2012). Further, Siikamaki and Krupnick (2014) note a substantial WTP to avoid a decline in surface water quality in rivers, streams, lakes, and reservoirs with water pollution problems from hydraulic fracturing.

Nonetheless we were unable to find data on systematic rates of surface water pollution for any of our 14 states. Therefore we have left this potentially important effect unquantified. We are hopeful that as more information becomes available analysts will be able to determine if surface water contamination is a substantial problem or not.

\subsubsection{Wildlife Habitat Fragmentation}

Fragmentation of wildlife habitat due to oil and gas development (well pads, access roads and other infrastructure including tanks for holding fluids) has been a long standing concern among wildlife biologists (Sawyer, et al. 2006; Copeland, et al. 2009; Drohan, et al. 2012). In Pennsylvania about half of the hydraulic fracturing occurs in forests (Drohan, et al. 2012). Impacts to wildlife go beyond the actual surface disturbance and include loss of habitat due to avoidance behavior from human activity, including noise. In particular, as noted by Sawyer, et al. (2006: 396) regarding mule deer and natural gas fields in Wyoming, "Changes in habitat selection appeared to be immediate (i.e., year 1 of development), and no evidence of well-pad acclimation occurred through the course of the study. Lower predicted probability of use within 2.7 to $3.7 \mathrm{~km}$ of well pads suggested indirect habitat losses may be substantially larger than direct habitat losses." The large extent of indirect habitat losses in the west may be due to the openness of the landscape with substantial sight distance due to sparse vegetation in many of the areas with hydraulic fracturing (e.g., Wyoming, Utah, western Colorado, etc.). 


\subsubsection{Quantifying Percent Wildlife Habitat Fragmentation}

Habitat loss has been quantified by Drohan, et al. (2012) for forests in the northcentral Appalachian area in the eastern U.S. We updated those estimates of total habitat disturbance using the current (2015) number of hydraulically fractured wells in (Fractracker Alliance, 2016) and find that $1.74 \%$ of forest habitat is lost due to hydraulic fracturing with a range of $0.75 \%$ (using a smaller direct disturbance of one ha drill pads and smaller spillover disturbance) to $2.28 \%$ (using the upper bound of their range of 2 ha drill pads instead of 1 ha and equivalent spillover). Finally we applied this rate of forest loss to the eastern U.S. states to estimate total forest habitat loss.

For the interior west, Copeland, et al. (2009) forecasted the potential loss of sagebrush habitat and sage-grouse populations from oil and gas development. The authors indicate their results apply to other species that use similar habitat such antelope, mule deer and several birds (Copeland, et al., 2009: 4). Their GIS analysis and modeling was based on what the U.S. Bureau of Land Management (the agency that oversees all federal mineral leasing on public lands) calls "reasonably foreseeable development" (Copeland, et al. 2009: 4). In addition, the authors determined that $81 \%$ of federal lands with potential for oil and gas had already been leased for oil and gas. Based on their analysis they calculated a total (direct and indirect) loss of $7 \%$ of wildlife habitat due to forecasted oil and gas development. While the authors did not separate out hydraulic fracturing from conventional oil and gas, two-thirds of natural gas wells use hydraulic fracturing (U.S. Energy Information Agency, 2015a) and one-half of oil wells involve hydraulic fracturing (U.S. Energy Information Agency, 2015b). Unfortunately we do not have data on habitat fragmentation related to hydraulic fracturing for California since the state is outside the geographic scope of either of the two articles.

\subsubsection{Economic Value of Habitat Fragmentation}

Siikamaki and Krupnick (2014) conducted a stated preference non-market valuation choice experiment to obtain willingness to pay to avoid wildlife habitat fragmentation in Pennsylvania and Texas (chosen to represent the eastern and western U.S.) They estimated that households would pay $\$ 48$ and $\$ 29$ to avoid a $1 \%$ increase in wildlife habitat fragmentation, respectively. We apply their estimates to the 13 of the 14 states (California is left out due to lack 
of data on habitat fragmentation). The loss due to wildlife habitat fragmentation is substantial$\$ 4.114$ billion in 13 of the 14 states, with a range of $\$ 3.5$ billion to $\$ 4.45$ billion.

\subsection{Non-Market Effects Omitted}

Besides the omission of the cost of surface water pollution, additional non-market effects that have been omitted include the effects of air pollution resulting from hydraulic fracturing of oil wells. This of course is important, but there are about half as many hydraulically fractured oil wells as gas wells. Nonetheless this is an important area for future research to fill. Another important cost which we have omitted is associated with induced seismic activity. In 2016 the U.S. Geological Survey published a one-year hazard forecast for seismic activity for the central and eastern U.S. (Peterson et al. 2016) and notes that induced seismic activity (attributable to human activity) has increased in the region due to underground injection of wastewater (a practice often employed to dispose of produced water from oil and gas drilling). The USGS report notes that these induced earthquakes are difficult to predict and therefore planners and builders are less apt to design for these seismic events making potential damage estimates difficult. Finally this analysis does not account for aesthetic losses beyond those reflected in property values

\section{Conclusions}

Like most energy sources, natural gas and oil produced using hydraulic fracturing yields both benefits and costs. At this time there are insufficient data to provide a complete economic analysis that would definitively determine whether the benefits of hydraulic fracturing outweigh the cost. In spite of this, our analysis is the most comprehensive to date, and we have estimated that market benefits of hydraulic fracturing include $\$ 75$ billion increase in consumer surplus to natural gas users (range $\$ 46$ billion to $\$ 95$ billion). Producer surplus from hydraulic fracturing is $\$ 7.24$ billion.

Non-market effects include the net environmental effects of air emissions (net of environmental benefits arising from hydraulic fracturing due to the substitution of natural gas for coal in electricity production):

- The net cost associated with air emissions from hydraulic fracturing is $\$ 17.5$ billion per year with a range from $\$ 9.76$ billion to $\$ 25.9$ billion. 
- Habitat fragmentation damages amounts to $\$ 4.11$ billion (range of $\$ 3.5$ billion to $\$ 4.45$ billion).

- Groundwater pollution of private drinking water wells due to surface spills at the well pad and infrastructure was estimated at $\$ 1$ billion (range of $\$ .5$ to $\$ 1.6$ billion). There was insufficient data to estimate the effects of underground contamination from hydraulic fracturing wells themselves on drinking water wells.

- There is also opportunity costs associated with the quantity of water used in drilling and reduced residential property value losses that together amount to about one-quarter of a billion dollars.

Not quantified are air pollution from oil wells that are hydraulically fractured (however, neither is the gain in consumer associated with lower oil prices), reduced surface water quality, reductions in non-market goods such as open space/aesthetics to non-property owners and seismic activity. Therefore a complete assessment of the benefits and costs of hydraulic fracturing awaits future research.

Nonetheless, there are certain insights that can be drawn from our analysis. Much of the controversy over hydraulic fracturing is not about whether there are net benefits to society, but rather how the benefits and costs are distributed. Given the perceived costs to those adversely affected by hydraulic fracturing, it is not irrational that they would seek bans, especially in suburban areas where jobs in occupations unrelated to oil and gas are plentiful and pay reasonably well. For those suburban residents living near hydraulically fractured wells the costs may outweigh the benefits, especially as Fry, et al. (2015) found in Denton, Texas nearly all the royalty money was flowing to mineral owners living elsewhere in Texas and outside of Texas rather than to adjacent homeowners.

Since a substantial amount of the hydraulic fracturing occurs in sparsely settled regions (e.g., northeastern Utah, Wyoming, western North Dakota) or predominantly rural areas, only a fraction of the U.S. population bears the environmental costs of fracturing but the benefits are spread throughout the U.S. Hydraulic fracturing in close proximity to suburban areas raises the non-market environmental costs since a given amount of pollution exposes orders of magnitude more people per well. However, the appropriate level of regulation or compensation to those who bear the cost of hydraulic fracturing requires detailed empirical economic studies of each geographic location. 
Acknowledgements: This research is supported by the Air-Water-Gas Sustainability Research Network funded by the National Science Foundation under Grant No. CBET-1240584. Any opinion, findings, and conclusions or recommendations expressed in this article are those of the authors and do not necessarily reflect the views of the National Science Foundation or Colorado State University. The authors wish to thank Dr. Jana Milford of University of Colorado-Boulder and Dr. Charles Abdalla, Pennsylvania State University for suggestions and comments on an earlier draft. The paper has benefit greatly from comments from two anonymous reviewers. The authors are of course responsible for any errors and omissions.

\section{References}

1. Adgate, J., B. Goldstein and L. McKenzie. 2014. Potential Public Health Hazards, Exposures and Health Effects from Unconventional Natural Gas Development. Environmental Science and Technology 48(15): 8307-8320.

2. API (American Petroleum Institute). 2013. Investment in U.S. Shale Well Drilling Surges in 2011. http://www.api.org/news-and-media/news/newsitems/2013/april-2013/investmentin-us-shale-well-drilling-surges-in-2011 (accessed August 1, 2015).

3. Bennett, A. and J. Loomis. 2015. Are House Prices Pulled Down or Pushed Up by Fracked Oil and Gas Wells? A Hedonic Price Analysis of Housing Values in Weld County. Society and Natural Resources. 28(11): 1168-1186.

4. Boslett, A., T. Guilfoos, and C. Lang. (2015). The Mineral Severance Legacy of the Homestead Acts: A Hedonic Valuation of Unconventional Oil and Gas Development in Colorado. University of Rhode Island, Providence, RI.

5. Bowen, Z. H., G. P. Oelsner, B. S. Cade, T. J. Gallegos, A. M. Farag, D. N. Mott, C. J. Potter, P. J. Cinotto, M. L. Clark, W. M. Kappel, T. M. kresse, C. P. melcher, S. S. Paschke, D. D. Susong, andn B. A. Varela. 2015. Assessment of surface water chloride and conductivity trends in areas of unconventional oil and gas development-why existing 
national data sets cannot tell us what we would like to know. Water Resources Research 51: 704-715, doi:10.1002/2014WR016382.

6. Boyer, E.W., B.R. Swistock, J. Clark, M. Madden, D.E Rizzo. 2012. The Impact of Marcellus Gas Drilling on Rural Drinking Water Supplies. The Center for Rural Pennsylvania. 28 p.

7. Center for Climate and Energy Solutions. 2013. Leveraging Natural Gas to Reduce Green House Gas emissions. http://www.c2es.org/publications/leveraging-natural-gas-reducegreenhouse-gas-emissions (accessed May 9, 2016).

8. Center for Rural Pennsylvania. 2014. Housing and Marcellus Shale Development: The Marcellus Impacts Project Report \#5. 34 p.

9. Clark, C. E. and J. A. Veil. 2009. Produced Water Volumes and Management Practices in the United States. Environmental Science Division, Argonne National Laboratory, Prepared for U.S. Department of Energy, Office of Fossil Energy, National Energy Technology Laboratory under Contract DE-AC02-06CH11357. 60 p.

10. Colby, B. G. 1989. Estimating the value of water in alternative uses. Natural Resources Journal 29: 511-527.

11. Copeland, H., K. Doherty, D. Naugle, A. Pocewiz and J. Kiesecker. 2009. Mapping Oil and Gas Development Potential in the U.S. Intermountain West and Estimating Impacts to Species. PLoS One. 4(10): 1-7.

12. Drohan, P., M. Brittingham, J. Bishop and K. Yoder. 2012. Early trends in landcover change and forest fragmentation due to shale-gas development in Pennsylvania: A potential outcome for the North Central Appalachians. Environmental Management 49(5): 10611075.

13. Drollette, B., and 12 other authors. 2015. Elevated levels of diesel range organic compounds in groundwater near Marcellus gas operations are derived from surface activities. Proceedings of the National Academy of Sciences 112(43): 13184-13189.

14. Ehrenberg, R. 1985. Workers Compensation, Wages and Risk of Injury. Working Paper 1538. National Bureau of Economic Research, Cambridge, MA. 
15. Fann, N., C. Fulcher, and B. Hubbell. 2009. The influences of location, source, and emission type in estimates of the human health benefits of reducing a ton of air pollution. Air Quality, Atmosphere and Health 2(3): 169-176.

16. Fann, N., K. Baker and C. Fulcher. 2012. Characterizing the PM2.5-related Health Benefits of Emission Reductions for 17 Industrial, Area, Mobile Emission Sectors Across the U.S. Environmental International 2012 (http://dx.doi.org/10.1016/j.envint.2012.08.017)

17. Fracktracker Alliance. 2016. Pennsylvania Oil and Gas Activity. http://www.fractracker.org/map/us/pennsylvania/ (accessed. March 16, 2016).

18. Freeman, A. M. 2003. The Measurement of Environmental and Resource Values: Theory and Methods. Second edition. Resources for the Future, Washington D.C. 491pp.

19. Fry, M., A. Briggle, and J. Kincaid. 2015. Fracking and Environmental (in)justice in a Texas City. Ecological Economics17: 97-107.

20. Gollehon, N., W. Quinby and M. Aillery. 2003. Water Use and Pricing in Agriculture, Chapter 2.1 in Agricultural Resources and Environmental Indicators, 2003, R. Heimlich, ed. USDA Economic Research Service, Washington DC.

21. Gollehon, N. and W. Quinby 2006. USDA's Chapter 2.1 of Agricultural Resources and Environmental Indicators. R. Heimlich, ed. USDA Economic Research Service, Washington DC.

22. Governing the States and Localities. http://www.governing.com/gov-data/energyenvironment/fracking-well-by-state-map.html (accessed April 5, 2016).

23. Hausman, C. and R. Kellogg. 2015. Welfare and Distributional Implications of Shale Gas. Working Paper 21115. National Bureau of Economic Research, Cambridge MA.

24. Holladay, S. and J. LaRiviere. 2013. The Effect of Abundant Natural Gas on Air Pollution From Electricity Production. Department of Economics, University of Tennessee. 45 p.

25. Holladay, S. and J. LaRiviere. 2014. The Impact of Cheap Natural Gas on Marginal Emissions from Electricity Generation and Implications for Energy Policy. Department of Economics, University of Tennessee. 44 p. 
26. Holland, S., E. Mansur, N. Muller and A. Yates. 2016. Are There Environmental Benefits from Driving Electric Vehicles? The Importance of Local Factors. American Economic Review 106(12): 3700-3729.

27. Howarth, R., R. Santoro and A. Ingraffea. 2011). Methane and Greenhouse-gas Footprint of National Gas from Shale Formations. Climatic Change 106: 679-691

28. Integra Realty Resources. 2010. Flower Mound Well Site Impact Study. Report prepared for the City of Flower Mound TX. Dallas, Texas. 108 p.

29. Interagency Working Group on Social Cost of Carbon. 2010. Technical Support DocumentSocial Cost of Carbon for Regulatory Impact Analysis-Under Executive Order 12866

30. International Panel on Climate Change. 2007. 2.10.2 Direct Global Warming Potentials. The Physical Science Basis. https://www.ipcc.ch/publications_and_data/ar4/wg1/en/ch2s210-2.html Accessed January 3, 2017.

31. Institute of Medicine. 2013. Health Impact Assessment of Shale Gas Extraction: Workshop Summary. Washington DC: The National Academies Press. 142 p. http://www.ncbi.nlm.nih.gov/books/NBK201904/ (accessed May 9, 2016).

32. Jackson, R. B., A. Vengosh, T. H. Darrah, N. R. Warner, A. Down, R. J. Poreda, S. G. Osborn, K. Zhao and J. D. Karr. 2013. Increased stray gas abundance in a subset of drinking water wells near Marcellus shale gas extraction. Proceedings of the National Academy of Science, 110 (28): 11250-11255.

33. Just, R., D. Hueth, A. Schmitz, and B. Griffith. The Welfare Economics of Public Policy, $2^{\text {nd }}$ Edition. Edward Elgar.

34. Kahrilas, G. A., J. Blotevogel, P. S. Stewart, and T. Borch. 2015. Biocides in hydraulic fracturing fluids: a critical review of their usage, mobility, degradation and toxicity. Environmental Science and Technology 49(1): 16-32.

35. Kappel, W. M., J. H. Williams, Z. Szabo. 2013. Water Resources and Shale Gas/Oil Production in the Appalachian Basin - Critical Issues and Evolving Developments. U.S. Department of the Interior, U.S. Geological Survey, Open-File Report 2013-1137 12 p.

36. Kinamann, T. 2011. The economic impact of shale gas extraction: A review of existing studies. Ecological Economics 70(7): 1243-1249 
37. Litovitz, A., A. Curtright, S. Abramzon, N. Burger and C. Samaras. 2013. Estimation of regional air-quality damages from Marcellus shale natural gas extraction in Pennsylvania. Environmental Research Letters 8: 1-9.

38. Long, J.C.S., and 31 other authors. 2015. An Independent Scientific Assessment of Well Stimulation in California, Volume II: Potential Environmental Impacts of Hydraulic Fracturing and Acid Stimulations. United States: California Council on Science and Technology. doi:10.2172/1236176

39. Loomis, J. 2002. Integrated Public Lands Management: Principles and Applications to National Forests, Parks, Wildlife Refuges and BLM Lands. Columbia University Press, New York, NY.

40. Lopez, R. 2012. Oil Boom's Benefits and Burdens: A Worker Influx Stresses Supply of Affordable Housing. Banking and Community Perspectives 3: 9-11.

41. Manning, A.J. 2015. Study: No water-based contaminants found in Colorado Wells. http://source.colostate.edu/study-no-water-based-contaminants-found-in-colorado-wells/ (accessed May 9, 2016).

42. Mason, C., L. Muehlenbachs, and S. Olmstead. 2015. The Economics of Shale Gas Development. Resources for the Future Discussion Paper, RFF-DP 14-42-REV.

43. Mauzerall, D.L., B. Sultan, N. Kim, D.F. Bradford. 2005. NOx emissions from large point sources: variability in ozone production, resulting health damages and economic costs. Atmospheric Environment 39:2851-2866.

44. McKenzie, L., W. Allshouse, T. Burke, B. Blair and J. Adgate. 2016. Population Size, Growth and Environmental Justice Near Oil and Gas Wells in Colorado. Environmental Science and Technology 50: 11471-11480.

45. Mehany, M.S.H. and A. Guggemos. 2015. A Literature Survey of Fracking Economics and Environmental Implications. Procedia Engineering 118: 169-176.

46. Michelsen, A. and R. Lacewell. 2013. Environmental and Related Impacts of Shale Gas Development: A Case Study of the Barnett Shale: Water Economics. Texas A\&M AgriLife Research, El Paso, TX. 
47. Muehlenbachs, L., Spiller, E., \& Timmins, C. (2014). The Housing Market Impact of Shale Gas Development. RFF DP 13-39 Rev, Resources for the Future, Washington DC. 48. Muller, N. and R. Mendelsohn. 2007. Measuring damages of air pollution in the United States. Journal of Environmental Economics and Management 54(1):1-14.

49. Newell, Richard G., and Daniel Raimi. 2014. Implications of Shale Gas Development for Climate Change. Environmental Science and Technology, 48(15): 8360-8368.

50. Nicot, J. and B. R. Scanlon. 2012. Water use for shale-gas production in Texas, U.S. Environmental Science and Technology 46(6): 3580-3586.

51. Olmstead, S. M., L. A. Muehlenbachs, J. Shih, Z. Chu and A. J. Krupnick. 2013. Shale gas development impacts on surface water quality in Pennsylvania. Proceedings of the National Academy of Science, 110(13): 4962-4967.

52. Osborn, S. G., A. Vengosh, N. R. Warner, and R. B. Jackson. 2011. Methane contamination of drinking water accompanying gas-well drilling and hydraulic fracturing. Proceedings of the National Academies of Science 180(20): 8172-8176.

53. Petersen, M.D., C.S. Mueller, M.P. Moschetti, S.M. Hoover, A.L. Llenos, W.L. Ellsworth, A.J. Michael, J.L. Rubinstein, A.F. McGarr, K.S. Rukstales. 2016. 2016 One-Year Seismic Hazard Forecast for the Central and Eastern United States from Induced and Natural Earthquakes: U.S. Geological Survey Open-File Report 2016-1035, 52 p. http://dx.doi.org/10.3133/ofr20161035 (accessed May 9, 2016).

55. Platt, J. 2013. Oil and fracking booms creating housing busts. MNN-Mother Nature Network. Environmental news and information. MNN-Mother Nature Network. http://www.mnn.com/earth-matters/energy/stories/oil-and-fracking-booms-creatinghousing-busts (accessed May 9, 2016).

55. Prince, M. and C. Tovar. 2015. How Much U.S. Oil and Gas Comes from Fracking? Wall Street Journal, April 1, 2015.

56. Rahm, B. G. and S. J. Riha. 2012. Toward strategic management of shale gas development: regional, collective impacts on water resources. Environmental Science and Policy 17: $12-23$. 
57. Sassone, P., and W. Schaffer. 1978. Cost-Benefit Analysis: A Handbook. Academic Press Inc., New York, NY.

58. Sawyer, H., R. Nielson, F. Lindzey and L. McDonald. 2006. Winter habitat selection of mule deer before and during development of a natural gas field. Journal of Wildlife Management 70(2): 396-403.

59. Siikamäki, J. and A. Krupnick. 2014. Information and the Willingness to Pay to Reduce Shale Gas Risks Contributed Paper, World Congress of Environmental and Resources Economists, Istanbul June 28-July 2, 2014. 47 p.

60. Sovoacool, B. 2014. Cornucopia or Curse? Reviewing the Costs and Benefits of Shale Gas Hydraulic Fracturing (Fracking). Renewable and Sustainable Energy Reviews. 37: 249264.

61. Swanepoel, G., J. Hadrich, and C. Goemans. 2015. Estimating the contribution of Groundwater Irrigation to Farmland Values in Phillips County, Colorado. Journal of the American Society of Farm Managers and Rural Appraisers. 2015: 166-179.

62. Thompson, C., J. Hueber and D. Helmig. forthcoming. Influence of Oil and Gas Emissions on Ambient Atmospheric Non-Methane Hydrocarbons in Residential Areas of Northeastern Colorado. Elementa: Science of the Anthropocene. doi: 10.12952/journal.elementa.000035

63. Throupe, R., R. Simons, Z. Mao. 2013. A Review of Hydro "Fracking" and Its Potential Effects on Real Estate. Journal of Real Estate Literature 21(2): 205-232.

64. U.S. Census Bureau, State and County Quickfacts, accessed April 28, 2016.

65. U.S. Energy Information Administration. 2015a. Shale in the United States. http://www.eia.gov/energy_in_brief/article/shale_in_the_united_states.cfm (accessed August 1, 2015),

66. U.S. Energy Information Administration. 2015b. International Energy Data and Analysis: United States. http://www.eia.gov/beta/international/country.cfm?iso=USA (accessed August 1, 2015).

67. U.S. Energy Information Administration. 2015c. Monthly Energy Review. https://www.eia.gov/ (accessed April 28, 2016). 
68. U.S. Energy Information Administration. 2016a. Hydraulically Fractured Wells provide Two-Thirds of U.S. National Gas Production. Today in Energy. May 5, 2016.

69. U.S. Energy Information Administration. 2016b. Hydraulically Fracturing Accounts for about Half of Current U.S. Crude Oil Production. Today in Energy. March 15, 2016.

70. U.S. Energy Information Administration. 2016c. Trends in U.S. Oil and Natural Gas Upstream Costs. U.S. Department of Energy, Washington DC.

71. U.S Environmental Protection Agency. 2010. Inventory of U.S. Greenhouse Gas Emissions and Sinks: 1998-2008. Washington DC. http://www.epa.gov/climatechange/Downloads/ghgemissions/508_Complete_GHG_1990 2008.pdf (accessed May 9, 2016)

72. U.S. Environmental Protection Agency. 2016. Technical Support Document for Technical Update on the Social Cost of Carbon for Regulatory Impact Analysis. Accesed 1-2-2017. https://www.epa.gov/sites/production/files/2016-12/documents/sc co2 tsd august_2016.pdf

73. U.S Environmental Protection Agency. 2014. Oil and Gas Sector Hydraulically Fractured Oil Well Completions and Associated Gas during Ongoing Production. http://www3.epa.gov/airquality/oilandgas/2014papers/20140415completions.pdf. (accessed October 17, 2015).

74. U.S. Environmental Protection Agency. 2015. Assessment of the Potential Impacts of Hydraulic Fracturing for Oil and Gas on Drinking Water Resources (External Review Draft). U.S. Environmental Protection Agency, Washington, DC, EPA/600/R-15/047, 2015. http://ofmpub.epa.gov/eims/eimscomm.getfile?p_download_id=523539 (accessed April 28, 2016).

75. U.S. Environmental Protection Agency. n.d. Greenhouse Gas Emissions: Methane. https://www.epa.gov/ghgemissions/overview-greenhouse-gases\#methane. Accessed January 3, 2017.

76. Vengosh, A., R. B. Jackson, N. Warner, T. H. Darrah, and A. Kondash. 2014. A critical review of the risks to water resources from unconventional shale gas development and 
hydraulic fracturing in the United States. Environmental Science and Technology 48(15): 8334-8348.

77. Ward, F. and A. Michelsen. 2002. The Economic Value of Water in Agriculture: Concepts and Policy Applications. Water Policy 4: 423-446.

78. Waskom, R., P. Oikonomou, J. Kallenberger and K. Boone. 2015. Presentation by Colorado State University Water Quantity Team, AWG NSF Site Visit, University of Colorado Boulder, June 10, 2015. 